\title{
A ficção literária nesse novo tempo
}

\author{
Lilian Fontes'
}

Resumo: Considerando que as narrativas ficcionais, sejam elas literárias ou audiovisuais, vêm sendo estudadas como um vasto campo para se obter dados referentes às características do imaginário contemporâneo no campo da estética, sociedade, cultura e política, portanto, como processo comunicacional, o presente artigo pretende abordar a influência da velocidade acelerada das novas tecnologias, dos meios de comunicação e da midia no pensamento estético atual e a sua relação com a produção ficcional literária.

Palavras-chaves: ficção) literária, estética da comunicação, recepção.

Abstract: Considering that the fictional narratives, being them literary or audiovisual, are being studied as a vast field to obtain data referring to the characteristics of the imaginary contemporary in the field of acsthetic, society, culture and politics, therefore, as communicational process, the present article intends to approach the influence of the sped up speed of the new technologies, the medias and the media in the current aesthetic thought and its relation with the literary fictional production.

Keywords: literary fiction, aesthetic of communication, receprion

Introdução:

Sabemos que no movimento da história, toda mudança técnica desestabiliza o antigo equilibrio das representaçóes, e nesta virada de século vimos que as novas tecnologias e a informática desenvolveram uma tal velocidade nos mecanismos que alteraram espantosamente o universo das representações até entào conhecidas. Os objetos di-

1 Fontes, Lilian: liscritora, com mestrado em Comunicaçào c Cultura, UFRJ. Participação e publicação nos anais de Congressos da Intercom $(2005 / 2006 / 2007)$, publicaçào ta revista Brasil-Brazil n"29. Workshop na Bron" Unitersity/ IUA. Scis livros publicados, mais participaçào cm 9 colctâncats. Ntualmente, cursando o doutorado em Comunicação-JíCO-UFR! li-mail-lilianfontes@tera.com.br. 
gitais, os computadores, telefones celulares, televisão a cabo, a internet, vieram estabelecer novas relações de comunicação, permitindo que informações fossem passadas num raio de espaço e de tempo cada vez mais curtos.

Essa relação inegável com os aparatos tecnológicos incide sobre todas as formas de enunciados, pensamentos e afetos, provocando transformações na produção de subjetividades, no imaginário do homem contemporâneo.

A ficção literária, como todas as artes, estará contaminada por essa nova maneira de atuar. Escrever, narrar, não consegue se abster deste processo. A interatividade criada por esses novos aparatos gerou uma linguagem articulada com múltiplos modos de expressão que trabalham simultaneamente. Além disso, o uso do computador, do processador de texto, veio agilizar o fazer literário provocando uma transformação na criação da narrativa ficcional literária.

As narrativas ficcionais, sejam elas literárias ou audiovisuais, vêm sendo uma rica fonte de estudo mostrando sua eficiente contribuição para se obter dados referentes às características do imaginário contemporâneo no campo da estética, sociedade, cultura e política, portanto, como processo comunicacional. Desde a epopéia clássica, as formas narrativas foram o meio de apreensão humana de mundo. Na Grécia arcaica, as palavras faziam parte do mundo das coisas e dos acontecimentos e as condições de sua enunciação representavam um signo a ser decifrado que revelaria o mundo do real e do oculto. Quem expunha essa "palavra" era o aedo, poeta-profeta, palavra portadora da alethéia, da verdade. Ele não inventava as suas histórias, ele apenas revelava as verdades, a fonte do presente e do passado. Portanto, a cultura grega já era atravessada pela noção de verdade muito antes do homem ocidental inventar o conhecimento. 'A pré-história da verdade filosófica corresponde uma verdade poética que foi o solo a partir da qual ou contra o qual se organizou o pensamento filosófico grego'(DETIENNE, 1988, cap.V).

Se considerarmos que a investigação lingüística e a etimologia, desde antigamente funciona como veículos de interpretação, representação e informação; a idéia de que o nome e a essência se correspondem; de que através da linguagem o real pode converter-se em objeto de captação intelectual; compreenderemos a importância da literatura na formação do pensamento, já que ela se fundamenta e se utiliza da linguagem, mais essencialmente da palavira. 
O papel da literatura, sobretudo da narrativa épica e do romance, prolonga em certo plano a narrativa mitológica. O romance tomou, na sociedade moderna o lugar ocupado pela recitação dos mitos e dos contos nas sociedades tradicionais

Porém, devemos lembrar que o romance se afirmou como objeto artístico - comparável à pintura, a escultura, a poesia - só a partir do século XVIII, no instante em que a narrativa assume o aspecto da imaginariedade, ou seja, mostrando o que há de imaginário no discurso da consciência de um "sujeito fictício", no caso, o personagem. A característica fundamental do romance é o fato de ter tornado a narrativa um exercício da escrita. Enquanto com os natradores épicos a narrativa era o canto, o advento do romance impõe a relação com a palavra escrita e com o ato de leitura. Na sociedade moderna a épica é o romance e o acesso à imaginação através da jinguagem, do estilo do autor é que elevará o texto literário ao estatuto de objeto artístico.

A partir de então, o texto literário passa a descrever cenários e personagens dentro de um certo realismo com a perspectiva de elucidar a essência do sujeito humano. O estilo do escritor, a forma como conduz a linguagem, irá revelar a capacidade de conduzir o leitor a um mundo real-ficcional construido através da palavra, estabelecendo uma relação direta $\mathrm{com}$ as suas sensações, que para os gregos é onde reside a Estética. O romance alcança o estatuto artístico quando a arte passa a ser entendida como expressão da vida humana, característica especifica da narrativa romanesca.

\section{A experiência estética:}

Na tradição clássica, a interpretação estética de Platão definia obra de arte pela sua capacidade de suscitar a beleza. $O$ valor de uso era inseparável da natureza e das necessidades do grupo social. A congruência da forma com o conteúdo, a relação entre a imitação (mimesis) e a criação, eram as questões supremas da reflexão filosófica da arte. Hegel definia o belo com o aparecimento sensivel da idéia, abrindo o caminho para teorias histórico-filosóficas da arte. Desde entào, a estética se concentrava no papel da apresentação da arte, ou seja, da obra e de seus autores, considerando-se apenas o lado produtivo da experiéncia estética, raramente o receptivo e quase nunca o comunicativo, que só passou a ser considerado a partir da "sociedade da comunicação". 
Se fossemos penetrar nas doutrinas de cada escola sobre a questão da estética levaríamos páginas e páginas, no entanto, para o nosso estudo o que nos interessa é saber que o primeiro problema colocado para se pensar a estética foi o que expõe Dufrenne ao dizer: ' $O$ que é o homem enquanto sensivel ao belo, isto é, enquanto capaz. de apreciar a beleza segundo a normatividade do gosto, e de produzi-la segundo os poderes da imaginação?'(DUFRENNE,1972, p.24).

Nesta concepção, percebemos que o belo é visto como um juízo de valor, ou seja, reconhece-se a qualidade de certo objeto quando este é apreendido segundo certa atitude que é a contemplação estética.

Portanto, a experiência estética desperta para o nascimento do sentido, pois se no sujeito humano existe uma necessidade de beleza experimentada pela apreciação das imagens, sejam na natureza ou em certos objetos, essa necessidade o atesta como ser sensível.

Neste contexto, a literatura se afirma por tratar de uma elaboração - seja poesia ou romance - racional e ao mesmo tempo imaginativa, levando ao leitor um universo onde a realidade e ficção se confundem, estimulando através da palavra sua sensibilidade e percepção.

A passagem do século XIX para o século XX foi marcada pela revolução causada pelos novos aparatos técnicos. As obras de arte, em determinadas modalidades tornaram-se tecnicamente reprodutíveis o que causou uma transformação significativa na questão relacionada à experiência estética. Este ponto é apresentado de modo preciso pelo ensaio de Walter Benjamin sobre A Obra de Arte na Era de sua Reprodutibilidade Técnica, de 1936, onde o autor apresenta as condições da arte contemporânea sob os efeitos da massificação e do mercado de consumo. A discussão sobre a autenticidade da obra de arte, a perda do aspecto da "aura", as modificações provocadas pela cultura de massa, pela sociedade de consumo, passou a ser preocupação de vários pensadores desde Adorno, Heidegger aos mais atuais, como Lyotard, Vattimo, Baudrillard, Maffesoli e outros.

Nas últimas décadas o conceito de arte vem sendo alterado visto a dificuldade de definir o objeto estético. Tivemos na década de 30/40, a visão negativista da Escola de Frankfurt devido à reprodutibilidade técnica e à cultura massificada. Na década de 60 , levanta-se a bandeira da "morte da arte" e de lá para cá a questão de sua existência tem sido colocada em constante cheque-mate quanto aos seus critérios estéticos.

Hoje vivemos no mundo da tela, da interface, da contigüidade e da rede, onde a circulação de imagens e informações numa veloci- 
dade instantânea estabelece uma indistinção, uma dificuldade de se fazer qualquer definição sobre determinado objeto.

Diante deste quadro, poderá se pensar a arte enquanto os conceitos de belo e do sublime? Como serão construídos os objetos artísticos e como se dará a percepção estética?

Em primeiro lugar, convém pensarmos que em função da "sociedade da comunicação" a obra de arte deixou de ser vista apenas pelo lado produtivo da experiência estética e passou a ser pensada quanto ao receptivo, ao comunicativo. Deste modo, verificou-se também que a própria mídia não mais se articula com uma ideologia definida, embora esteja diretamente atrelada ao mercado de consumo, à sociedade industrial, mas sua força está na capacidade de convencimento, de sedução e de captar o que o consumidor sinaliza. Sendo assim, ela incorpora eventuais demandas que nào estavam em seu discurso funcionando como instância organizadora da vida cotidiana e do próprio imaginário social. Vivendo numa sociedade midiatizada, a cultura estará imediatamente associada à mídia e toda modalidade de arte vinculada como ato de comunicação cultural. Portanto, como mostra Denílson Lopes:

A recuperação da estética na atualidade passa menos pelo elogio monumentalizador das (neo)vanguardas do que pela aproximação da arte com uma vida cotidiana, marcada pelas imagens midiáticas, fundamentais para entender a cultura contemporanea não só ao se falar das condiçōes de produção e de recepção, mas na análise da mensagem, do produto, da obra' (LOPES, 2007, p.23).

Sendo assim, a literatura não mais se dirige unicamente à cultura letrada, mas está atticulada com outras categorias de linguagem como o cinema, $T V$, indústria fonográfica, jornais e revistas. Percebese, portanto, um movimento na criaçào literária de encarar o texto como um veículo de comunicação.

A obra literária só se pode considerar realizada, ao ser acolhida pelo leitor, não que o autor tenha como premissa ao realizar a sua obra o pensamento no leitor. Sabemos que o autor quando cria, se vê a priori envolvido com um tema que o interessa e, a partir dai, desenvolve vai captar no texto, no livro, o pensamento, a ideologia que o autor quer transmitir. A obra ao ser fejta já está diretamente associada à possibilidade de leitura. É o leitor que irá propagar e, por sua vez, 
não deixar esgotar a escritura. Através do leitor a obra se comunica. Deste modo, o texto postula o leitor como condição indispensável para a capacidade concreta de comunicação.

A relação autor-leitor vem sendo analisada pelos teóricos da estética da recep̧̧ão - dentre eles se destaca os alemães, H.R. Jauss, W. Iser, K. Stierle, e H.U. Gumbrecth - que consideram a literatura enquanto produção, recep̧̧ão e comunicaf̧ão, uma relação dinâmica entre autor, obra e público. Sob este prisma, o ato de leitura passa a ter um duplo horizonte, o implicado pela obra e o projetado pelo leitor de determinada sociedade, considerando suas condições sócio-históricas.

Um texto distingue-se de outros tipos de expressão porque conta unicamente com o aspecto lingüístico. $\mathrm{Na}$ comunicação face a face entram infinitas outras formas, como a gestual, onde mais sistema de signos se completam reciprocamente. Na produção de um texto, o autor deverá fazer uma série de referências que confiram conteúdo às expressões que usa. As ações passadas pelos personagens no texto terão de ser expressas através de referências textuais. Deste modo, o texto postula o leitor como condição indispensável para a capacidade concreta de comunicação.

O produtor de um texto seja ele teórico ou de ficção, preverá um Leitor-modelo (ECO, 1979) capaz de cooperar com a atualização do texto. Cria-se, então, uma dialética entre a estratégia do autor e a resposta do leitor, a sua capacidade de absorção do texto. Vemos aqui ocorrer dois tipos de estratégia: o autor, enquanto sujeito da enunciação textual, formula uma hipótese de leitor-modelo que irá dirigi-lo na própria operação textual. Por sua vez, o leitor empírico, também configura para si uma hipótese de autor deduzindo-a exatamente a partir dos dados fornecidos pelo texto. No entanto, a hipótese formulada pelo Leitor acerca do autor é mais garantida, pois sendo o texto assinado, pode-se saber sobre a ideologia do autor. Já para o autor, mesmo que durante a produção do texto ele tenha em mente um leitor-modelo, este leitor sempre será empírico e por sua vez imprevisível.

Independentemente de estarmos diante de um texto ficcional, historiográfico ou científico, observa-se que tanto o autor e o leitor estão presentes no texto. A cooperação textual é fenômeno que se realiza entre duas estratégias discursivas e não entre dois sujeitos individuais. Portanto, o texto literário não mais pode ser enquadrado dentro de uma visão da arte próxima ao absoluto, como no passado, mas como um auxiliar da cultura onde a linguagem atua como discurso informativo e questionador. 
Dentro desta análise, considera-se o leitor como um receptor ativo, capaz de compreender os códigos emitidos pelo texto. Isto, evidentemente, dependerá de seu perfil intelectual, que determinará o êxito do texto para que ele seja plenamente compreendido no seu conteúdo potencial. Aqui se delineia o estatuto das "interpretações" sociológicas e psicanalíticas dos textos, em que procura se descobrir o que o texto, independente da intenção do autor, de fato diz. Entrarcmos, então, na questão daquilo que Barthes chama de texto de fruição ou gozo, ou seja, se o texto é usado como texto de fruição ou se $o$ ato de leitura estimula o uso livre do discurso, o que nos encaminha a avaliar a questão da experiência estética, visto que esta nào se inicia pela compreensão e interpretação do significado de uma obra e nem da reconstrução da intenção de seu autor. A experiência primária de uma obra se realiza na sintonia com seu efeito estético, na sua fruição.(BARTHES, 1987. p.36).

Cabe agora pensarmos nesta interação texto-leitor na estrutura social contemporânea. Se considerarmos a incidencia das mídias eletrônicas, das novas tecnologias e da informática na produção de novas formas de saber, veremos a tendência cada vez maior de integração de mecanismos de comunicação capazes de conectar informações de diferentes regiões do planeta. Desta forma, a questão da recepção tem de ser reavaliada assim como o efeito estético.

Por mais terrivel que possa parecer aos puristas da critica ideológica a situação das artes sob o domínio dos novos mass media, o que podemos observar é que realmente a visão vanguardista da arte nào pode mais pensar no receptor apenas de uma camada "culta" da sociedade. A velocidade imposta ao pensamento humano pela ingerência das novas tecnologias, a comunicação infográfica que universaliza em um tempo rapidíssimo as informaçōes, abre um círculo de destinatários, ou seja, de receptores nunca imaginado e sobre este aspecto é que teremos de pensar a obra, a produção de textos, sejam eles teóricos ou ficcionais.

Há os que defendem, como Baudrillard, que vivemos a época da estetização geral da vida cotidiana, da banalização. Na visão de Henri-Pierre Jeudy, o excesso de escolhas, a falta de ideologia, de um pensamento crítico, cria um vazio. Já Michel Maffesoli, reage a esta posição pessinnista propondo uma leitura não-moralista desta liberdade acreditando na constituição de uma "ética da estética" como antídoto do vale-tudo. 
Retomando o trabalho de Denilson Lopes seria olhar a questão estética numa outra perspectiva.

\begin{abstract}
'Uma estética centrada na experiência, palavra ardilosa, múltipla, que traz uma tensão constante entre a possibilidade de acúmulo, transmissão, comunicação e conversação ou/e sua impossibilidade. Esta experiência está sempre além da arte, mas afirma o lugar desta como forma de conhecimento e de estar no mundo. Uma estética da comunicação, não dos meios de comunicação. (LOPES, 2007, p.30).
\end{abstract}

Dentro destas posições, pergunta-se se haveria no autor de uma obra literária a intenção de satisfazer o desejo de um leitor vínculado ao mercado, às novas mídias.

A função do autor é muita bem elaborada por Foucault quando diz que 'a função de um autor é caracterizar a existência, a circuląão e a operatividade de certos discursos numa dada sociedade'. (FOUCAULT, 1992, p21) Ao escrever o texto, seja de ficção ou teórico, o autor, ao mesmo tempo que estará conduzindo uma idéia, estará se colocando fora dela, estará servindo como iniciador de uma prática discursiva, onde o sujeito dissolve-se perante as variáveis deste discurso. Jacques Derrida em seu estudo sobre a escritura, revela que

'Escrever é querer atingir o ser fora do sendo(...) escrever é retirar-se. Não para a sua tenda para escrever, mas da sua própria escriturá cair longe da sua linguagem, emancipá-la ou desampará-la, deixá-la caminhar sozinha e desmunida'. (DERRIDA, 1971, p.27)

Portanto, podemos encarar o autor como um veículo que, ao encerrar o seu texto, perde a sua identidade, o seu próprio nome passa a ter a função de uma determinada classificação de um determinado texto, que ao ser lido, atingindo a sua função perante os leitores, se pergunta, "Que importa quem o escreveu?".

Por sua vez, o leitor destes novos tempos está contaminado pela velocidade dos acontecimentos em um mundo técnico-científico que atua nos nossos órgãos sensoriais, provocando outros comportamentos. Portanto, a produção literária atual estará conectada com este tipo de sujeito. 


\section{O receptor informatizado:}

A informática veio trazer uma nova condição à questão da recepção. Mal os pensadores começaram a entender a importância do receptor na experiência estética tanto nas artes visuais quanto na literária, tiveram que se deparar com um novo modelo, o da interatividade. Esta interconexão, estudada por Pierre Lévy dentro do conceito de ciberespaç, serve para designar os diversos modos de hibridação articulados com os novos dispositivos tecnológicos: multimídia interativa, o hipertexto, a realidade virtual.
'Le cyberespace constitue un champ vaste, ouvert, en- core partielment indeterminé, qu'il ne faut pas réduire à une seule de ses composantes. Il a vocation à inter- connecter et interfacer tous les dispositifs de création, d'enregistrement, de communication et de simulation.' (LEVY, 1994, p.119).

Pierre Levy chama a atenção para o surgimento de uma inteligência coletiva cuja linguagem está articulada com múltiplos modos de expressão, que trabalham simultaneamente gerando um plano semiótico desterritorializado.

'Il est probable que le langage humain soit apparu simultanément sous plusiers formes: orale, gestuelle, musicale, iconique, plastique, chaque expression singulière activant telle ou telle zone d'un sens àl'autre, suivant les rhizomes de la signification, atteignant d'autant mieux aux puissances de l'espirit qu'elle traversait le corps et les affects.' (Ibidem, p.120)

Nestas condições, o psiquismo de um individuo estará dirigido para uma nova maneira de pensar, de absorver conhecimentos, de sentir, conduzindo-o a novas modalidades expressivas de subjetivação.

Deste modo, a produção artística estará necessariamente vinculada a este receptor que exigirá dinamismo, num sistema aberto de agenciamento entre a obra de arte e o intérprete. A distinção entre autor e leitor, produtor e espectador tende a desaparecer. 
'Or l'environnement technoculturel émergent suscite le développement de nouvelles espéces d'art, ignorant la séparation entre l'émission et la réception, la composition et l'interprétation.(.) Cette nouvelle forme d'art fait expérimenter à ce qui n'est justement plus un public d'autres modalités de communication et de création.'(Ibiden, p.123).

Sendo assim, uma nova relação é criada. O objeto artístico transforma-se num "lugar" explorável, mas este lugar não é um puro "espaço" como pensava Kant, um simples substrato dentro do qual a experiência viria inscrever-se. Ele é o próprio objeto da experiência e esta relação entre o artista e o receptor estabelece ligações inéditas entre preceitos e conceitos, entre fenômenos perceptíveis. Podemos dizer, então, que a nova arte difere das artes tradicionais, pelo fato de acentuar mais o processo do que a obra acabada. Seria a idéia da "obra aberta" de Umberto Eco (década de 70) elevada a outras instâncias: a obra de arte atual ultrapassa as coordenadas tradicionais de tempo e espaço, ela não se encerra no ciclo de sua criação, mas amplia-se convidando o intérprete a explorar vários sentidos e possibilidades, a-temporais, a-espaciais, a-significantes, no reino do nomadismo generalizado.

$\mathrm{Na}$ era da tecnologia e da velocidade, escrever tornou-se um hábito, auxiliado pelo advento da informática que agilizou a elaboração do livro. Se é verdade que o leitor se indentifica hoje em dia com o texto ágil, e que o autor está cada vez mais sintonizado com este leitor que irá usufruir de seu texto, isto provoca uma reestruturação da narrativa tendo reflexo imediato nas enunciações e enunciados e na apresentação do sujeito.

Diante deste quadro, percebemos que a obra literária sofre umatransformação na forma de apresentar a história ao leitor. Não há a preocupação, por exemplo, de definir os personagens já no início da narrativa; os personagens vão se definindo pelas experiências narradas, deixando ao leitor a interpretação mais ajustável. Amplia-se o leque estimulado ainda mais pelo mercado que engole toda e qualquer atividade atrelando-a imediatamente ao consumo imediato.

E o texto literário? Quais as implicações sentidas na narrativa, desta nova situação? 


\section{O texto literário atual:}

Sabendo que as ficções literárias funcionam como mediação existencial entre o sujeito e o mundo, e que, portanto, se torna o portador imediato do saber e de expressão do imaginário social de determinada época, pensar a literatura hoje recai numa posiçào onde a preocupação não é mais a representação ou a anti-representação, mas a produção de um real que se desdobra em paradoxos, na desconstrução do sujeito enquanto os seus antigos perfis.

Desde o nilismo niestzscheano quando a descrença no absoluto abriu o pensamento para além do bem e do mal e colocou o homem diante de sua finitude, o sujeito humano passou a ser pensado na experiência e no tempo, tempo este que nào conseqüente, mas no instante, no que é produzido em ato. (ANTOUM, 1993 p . 170-17).

$O$ discurso pós-modernista dos anos 80 virá propor uma abertura quanto à situação da ficção. Ao marcar que o contexto histórico se insere como valores significantes, irá romper com as fronteiras entre os gêneros literários criando, como denomina Linda Hutcheon, uma "metaficção historiográfica", ou seja, uma ficção que se apropria de acontecimentos e personagens históricos para criar uma nova ficção, abrindo espaço para a paródia, para o pastiche. Assumindo o desenvolvimento da cultura de massa como uma realidade social decorrente do capitalismo mais recente, o pós-modernismo ensina que atualmente a arte, a política está estruturada por discursos. Veremos, portanto, ocorrer uma intertextualidade onde romances de diferentes gèneros funcionam como um mejo de abordar questões fllosóficas, da sociologia, da ciência política, da própria literatura, etc.

O pós-modernismo não chegou a criar escola, mas serviu como abertura para o surgimento de algo novo.

Considerando a posição de Terry Eagleton apresentado por Linda Hutcheon, ele apresenta três períodos para a histótia da teoria moderna que corresponde às mudançcas literárias dos últimos anos: uma preocupação com o autor (romantismo e século XIX); uma preocupação exclusiva com o texto (Nem Cristicism); e uma mudança da atenção para o leitor nos últimos anos. Podemos apontar que o pós-modernismo recusa a onisciência da terceira pessoa e propõe un diálogo entre a voz narrativa e um leitor imaginário.

$\mathrm{Na}$ narrativa atual observa-se uma maior incidência do uso do narrador em primeira pessoa como forma de dinamizar a ação 
do personagem. Contaminados pela velocidade dos novos tempos e pela influência da imagem no nosso imaginário, prevalece a preocupação de estabelecer uma escrita que se desenvolva pela ação dos seus personagens.

Quando James Joyce rompeu com as regras do diálogo como única forma de conduzir o pensamento dos personagens, não previa que estaria concedendo um método condizente com a velocidade imposta ao sujeito neste novo tempo. A identidade do narrador está diretamente associada as suas experiências, ao tempo que corre, e o seu discurso funciona como um vetor para despertar o leitor para suas reflexões. O fluxo de consciência, o monólogo interior, o diálogo incluso, atuam em primeira pessoa, criando uma zona de contato tênue entre o autor e o leitor. Não soa como a palavra ideológica autoritária exterior (BAKHTIN, 1993. p.145). mas como ato de fala, como uma voz que penetra incisivamente no cérebro do leitor. A narrativa em primeira pessoa que a princípio estaria colocando a opinião do personagem, na verdade abre um campo para que o leitor, através de sua percepção, ingresse num relacionamento tenso onde o que importa não são as opiniões, as ideologias, mas as questões vividas num presente imediato, num tempo inacabado onde tudo está sujeito ao acaso.

Os escritores dos últimos tempos em nada se parecem como os escritores do século passado, envoltos em seus pensamentos, isolados em sua "torre de marfim". Escrever, atualmente, se tornou um ato dinâmico articulado com inúmeras informações recebidas das mais variadas formas: cinema, TV, internet, música, jornais, revistas.

Autores como Fernando Bonassi, Patrícia Melo, Marçal Aquino. André Sant'anna, só para citar uns exemplos, aplicam em suas narrativas, modos de linguagem que se coadunam com este ritmo acelerado. Adotam os periodos curtos, sem conjunção aditiva para comunicar com brevidade e rapidez. Seus personagens vão sendo definidos pelas experiências narradas, pela ação, não havendo descrições reflexivas.

Este ponto nọs remete à influência do cinema que privilegia a ação no imaginário destes escritores. Sem querer entrar na análise dos temas escolhidos para suas histórias, é interessante observar que a forma de narrar transcreve a situação como se os personagens estivessem entrando em cena. Como na narrativa de Patrícia Melo: 'A mãe aparece, ágil, decidida, as duas mãos ajeitando o cabelo. Aproveita o espelho da sala e retoca o batom'. (MELO, 1994, p.35).

A própria autora, em certa entrevista declarou: "O cinema e a TV mudaram o nosso jeito de escrever e a forma das pessoas lerem. Acho que no nosso caso, a literatura tem textura de película." 
No livro Sexo, de André Sant'ana, os personagens são nomeados pelas suas características apresentadas pelas suas ações e não por um nome: o Executivo De Óculos Ray-ban, a Secretária L_oura Bronzedada Pelo Sol, a Adolescente Meio Hippie.

Outro ponto interessante é observar que na natrativa clássica, a repetição de termos num mesmo parágrafo era tido como uma agressão ao texto. Fazia-se esforço para tentar encontrar sinônimos, metáforas que pudessem "limpar" o texto. Na narrativa atual, o uso de reiterações atua como se quisesse, através delas, evocar imagens mentais no cérebro do leitor, na intenção de despertá-lo para uma reflexão. Como exemplo, em Patrícia Melo: 'Rubrio, oito. A mãe aparece. Batom. Vagabunda. Atrás dela bá um bolo. Dentes. Vagabunda. Luta. Mãos envolven o pescoco da vagabunda'.(Ibidem, p.49).

Convém lembrarmos que ao longo da história o texto literário vem se impondo como espaço de experimentação, de recursos múltiplos que substituem a unidade de enunciados, tornando-se o principal personagem da evolução literária na era moderna por ser o veículo de expressão das tendências evolutivas do novo mundo. 'O romance é o único gênero em evoluçào, por isso ele reflete mais profundamente, mais substancialmente, mais sensivelmente e mais rapidamente a evolução da própria realidade.' (BAKTIN, 1993, p.400).

Numa época de rupturas de crenças e valores, e que a inadequação dos modelos clássicos cedem lugar à multiplicidade de paradigmas, a sociedade se mostra muito mais complexa. A globalização neoliberal e as trocas culturais informatizadas embaralharam os simbolos de identidade de cada cultura. Em alguns autores, certas histórias não têm um território definido, um sujeito definido. Na literatura brasileira, João Gilberto Noll e Bernardo Carvalho são claros representantes desta vertente. Seus personagens não têm sexualidades definidas, circulam por espaços cambiantes, têm destinos cambiantes, sujeitos aos acontecimentos, firmando a posição do efêmero, do se viver pelo presente e nào mais para o futuro.

Para os puristas, a literatura vem perdendo sua força de reflexào para uma narrativa mais preocupada em fazer alianças com o mercado das linguagens da imagem que privilegia a ação.

E pensar a literatura numa época onde a cultura está vinculada às leis do mercado pondo em risco os valores essenciais da obra de arte, faz com que alguns pensadores se perguntem "Para onde vai a literatura? 
Se existe uma resposta, eu diria que a literatura vai para ela própria, para a sua essência que é escapar de toda determinação, de qualquer afirmação e se manter fiel à força da palavra escrita, levando ao leitor um universo onde a realidade e ficção se confundem, atuando como fenômeno comunicacional, sobrevivendo e se coadunando com as mudanças de todas as épocas. 


\section{Referências:}

Antrum, Henrique. As Aspas as Raspas em Niefacbe e Benjamim; o problema do eterno retorno na produção da cultura e da bistónia. Tese de doutorado, ECO. Ufri, 1993.

Aron, Raymond. História da Estética. Lisboa: Editora Estampa.

Baktin, Mikail. Estética da Criagão Verbal. São Paulo:Martins Fontes, 1992.

Unesp. 1993 - Questoes de Isteratura e Estética. A teoriu do Romance. Editora

Barthes, Roland. Mitologias. Rio de Janeito: Bertrand Brasil, 1989. , O Rumor da Lingua. Ljsboa: Edições 70, 1987.

Baudrillard, Jean. A Transparência do Mat; ensaio sobre os fenômenos cxtremos. Campinas, SP: Papirus, 1990.

Benjamim, Walter. "O autor como produtor". In: Obras esolbidar.São Paulo, Brasiliense, 1985. v1. "A obra de arte na era da reprodutibilidade técnica." (1 versão). In: Obras escolljidas .São Paulo, Brasiliense, 1985. v.1.

Derrida, Jacques. A Escritura e a Diferença. São Paulo: Editora Perspectiva, 1971.

Dufrenne, Mikel. Estética e Filosofia. Sp: Editora Perspectiva, 1972.

Eco, Umberto. Olra Aberta. São Paulo: Editora Perspectiva. 1976 I ector in Fabula. São Paulo: Editora Perspectiva, 1986.

Foucault, Michel. O que é o Autor? Lisbora:Vega, 1992.

Hutcheon, Linda. Poética do Pás-modermismo. Rio de Janeiro: Imago Editora, 1991.

Iser, Wolfgang. O Ato da Leitura. Rio de Janeiro: Editom 34, 1996.

Jameson, Frederic. Espago e lmagem. Rio de Janeiro: Ed. UFRJ, 1994.

Jeudy, Henri-Pierre. I es Ruses de la Communication. L'Euthanaie des Sages. Paris.

Lévy. Pierre. As Tecnologias da Inteligência. Rio de Janeiro: Editora 34, 1994.

Éditions lá Découverte, 1994. L'Intelligence Collective: pour une antbropologie du cyerspace. Paris: , O que éo Virtual. Rio de Janeiro: Ed.34, 1996.

Lopes, Denílson. A delicadeza; estética, experiência e paisagens. Brasília: Editora Universidade de Brasilia:Finatec, 2007.

Melo, Patricia. Acqua toffana. São Paulo: Companhia das l_ctras, 1994.

Maffesoli, Michel. No Fundo das Aparências. Petropolis, RJ: Editom Vozes, 1996.

Sant'ana, André. Sexo. Rio de Janeiro: Sette l_etras, 2001.

Tavares D'Amaral, Marcio (org.). Contemporaneidades a Nonas Tecnologia. Rio de Janeiro: Sette Letras, 1996. 
180 